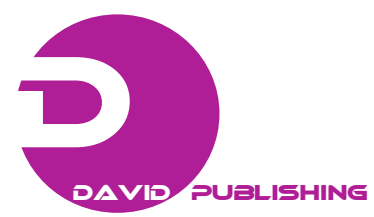

\title{
Comparison of Interfacial and Foaming Properties of Soy and Whey Protein Isolates
}

\author{
Cecilia Abirached ${ }^{1}$, Claudia Alejandra Medrano ${ }^{1}$, Ana Claudia Araujo ${ }^{1}$, Patrick Moyna ${ }^{2}$, Maria Cristina Añón ${ }^{3}$ \\ and Luis Alberto Panizzolo ${ }^{1}$ \\ 1. Food Science and Technology Departament, Facultad de Química, Universidad de la República, Montevideo 11800, Uruguay \\ 2. DEPTEQ, Facultad de Química, Universidad de la República, Montevideo 11800, Uruguay \\ 3. CIDCA-CONICET-UNLP, La Plata 1900, Argentina
}

Received: April 25, 2012 / Published: July 20, 2012.

\begin{abstract}
A comparative study on the foaming properties and behavior at the air-water interface of soy and whey protein isolates were made. Foams were obtained by the method of gas bubbling. The initial rate of passage of liquid to the foam ( $\left.\mathrm{v}_{\mathrm{i}}\right)$ and the maximum volume of liquid incorporated to the foam (VLEmax) were determined. The destabilization process of the formed foams was analyzed by a biphasic second order equation. Measurements of equilibrium surface tension (water/air) and surface rheological properties were carried out in a dynamic drop tensiometer. The foaming capacity ( $\mathrm{v}_{\mathrm{i}}$ and VLEmax) and the stability of foams prepared with the whey protein isolates (WPI) were better than those formulated with the soy protein isolates (SPI). WPI foams were more stable showing the lower values of rate constants of gravity drainage and disproportion. There were significant differences $(P \leq 0.05)$ in the dilatational modulus in the surface rheology measurements, which were higher at the interface with WPI, implying greater resistance of the film formed to collapse and disproportion. In conclusion, WPI formed better and more stable foams than the SPI.
\end{abstract}

Key words: Soy protein isolates (SPI), whey protein isolates (WPI), disproportion, gravitational drainage.

\section{Introduction}

Many natural or processed foods are dispersions or have been dispersions during a stage of its production. Most of these dispersions are foams. Therefore, the analysis of food dispersions or colloids is of great practical importance [1].

Food dispersions are thermodynamically unstable. From a practical standpoint it is possible to produce a kinetically stable (or metastable) dispersion for a reasonable period of time, which is what the consumer demands for products [1].

Foams are dispersions of air bubbles in a liquid medium containing a surface active agent, also known as foaming agent. The surface active agent tends to be on the surface of the bubbles, protecting them from the

Corresponding author: Cecilia Abirached, food engineer, researcher, research field: proteins functionality. E-mail: abirached@fq.edu.uy. collapse. The composition and properties of the adsorbed layer determines the resulting stability and physical properties of the foam [2].

The process of destabilization of foam is the tendency of the discontinuous gas phase to form a continuous phase by approximation and fusion of the bubbles, achieving a minimum surface area (minimum free energy). This process is opposed by the protein surface film, which as a mechanical barrier the more effective it is, the greater their viscoelasticity and rigidity are. The mechanisms of foam destabilization are liquid drainage by the effect of gravity, disproportion or Ostwald ripening, in which large bubbles grow at the expense of small bubbles by gas diffusion through the lamellae, and collapse of the foam by lamellae rupture. All of these mechanisms occur simultaneously and synergistically [3].

There have been several studies of the kinetics of 
foam destabilization. Previous works studied the foam destabilization by a specific rate constant of drainage that does not differentiate between the various processes of destabilization [4-8]. Panizzolo and collaborators [9] proposed that there are two distinct processes of fluid drainage from the foam, one due to fluid drainage itself and another to the Ostwald ripening. On this basis, a two-phase second-order model which determines the rate constants and maximum volumes drained due to gravity drainage and disproportion was considered [9].

In the present work we study the foaming properties of the whey protein isolate (WPI) and the soy protein isolate (SPI). Both of whey and soy proteins are by-products of the industry.

The functional properties of whey proteins are given by the $\alpha$-lactalbumin and $\beta$-lactoglobulin (main components) properties. Among them are its solubility, emulsifying and foaming properties and the gelling ability [10-12].

Isolated soy proteins are manufactured from defatted soy flakes by separation of the soy proteins from both the soluble and the insoluble carbohydrate fractions of the soybean.

Functionality is determined, in a large part, by the specific processing parameters used for the manufacture of a given isolated soy protein. Gelation, emulsification, viscosity, water binding, dispersebility, and foaming or whipping properties are important functional characteristics associated with isolated soy proteins [13].

There are many studies on the literature of the foaming properties of whey [14-17] and soy protein isolates $[8,18-20]$. but there no comparative studies between them.

Therefore, the objective of this work is to conduct a comparative study on the foam ability and foam destabilization by gravitational drainage and disproportion of bovine whey and soy protein isolates and relates them with the behavior at the air-water interface.

\section{Materials and Methods}

\subsection{Materials}

The bovine whey protein isolate (WPI) used was BiPRO from Davisco Foods (Le Sueur, MN), with a protein content on dry basis of $97.6 \% \pm 0.3 \%$. All other chemicals and reagents were of analytical grade from Sigma Chemical Co. (St. Louis, MO).

\subsection{Soy Protein Isolation}

Soy protein isolate (SPI) was obtained by aqueous solubilization of defatted soy flour (Sanbra, S.A., Sao Pablo, Brazil) at $\mathrm{pH} 8.0$, followed by precipitation at $\mathrm{pH} 4.5$, dispersion of the precipitate on alkaline medium ( $\mathrm{pH}$ 8.0) and freeze-drying [21]. Protein content was determined by Lowry method [22].

\subsection{Protein Solubility}

The solubility's of SPI and WPI were determined by dispersion of the proteins in $10 \mathrm{mM}$ sodium phosphate buffer $\mathrm{pH} 8.0$, stirring during 30 minutes at room temperature to make a solution of $0.1 \% \mathrm{w} / \mathrm{v}$. Then the dispersions were centrifuged at $10,000 \mathrm{~g}$ for 10 minutes at $4{ }^{\circ} \mathrm{C}$ and the protein content was determined in the supernatant using the Lowry method [22].

\subsection{Surface Hydrophobicity}

Surface hydrophobicity of SPI and WPI was evaluated using ANS (8-anilino-1-naphthalenesulfonic acid) as fluorescent probe [23]. Spectrofluorometric measurements were taken at $\mathrm{pH} 8.0$ on an Aminco-Bowman Series 2 Luminescence spectrometer. The fluorescence intensity of the blank (FIb) and of the ANS-protein conjugate (FIe) were recorded at wave length $\lambda_{\text {excitation }}=363 \mathrm{~nm}$ and $\lambda_{\text {emission }}=475 \mathrm{~nm}$, using $5 \mathrm{~nm}$ emission and excitation slit widths. The surface hydrophobicity (So) was obtained graphically using the Kato and Nakai equation [24]. A plot of (FI\%) versus (PC) was drawn, where (PC) is the protein concentration; $(\mathrm{FI} \%)=(\mathrm{FIN}) /(\mathrm{FImax}) ;(\mathrm{FIN})=$ (FIe)-(FIb); FImax is the maximum fluorescence 
measured from the total binding of ANS in methanol.

\subsection{Foaming Capacity}

The foaming properties of SPI and WPI were determined by conductimetry using the method and device developed by Loisel, Guéguen, and Popineau [25]. Foam was formed by air sparging into the protein solution in a column with a fretted glass disk at the bottom. The test was performed with $1 \mathrm{mg} / \mathrm{mL}$ protein dispersion in sodium phosphate buffer $0.1 \mathrm{M}, \mathrm{pH} 8.0$ and an ionic strength of 0.28 .

The level of the solution as a function of time was measured by conductimetry with a pair of electrodes located at the base of the column. To evaluate the foaming capacity, the maximal volume of liquid retained in the foam (VLEmax) and the initial rate of liquid transfer to the foam $\left(\mathrm{v}_{\mathrm{i}}\right)$ were measured [15].

The kinetics of destabilization was determined by applying the kinetic model developed by Panizzolo [9]. There are two different processes of drainage of fluid from the foam, one due to fluid drainage itself and another to the Ostwald ripening.

$$
V(t)=\frac{V_{g}^{2} k_{g} t}{\left(V_{g} k_{g} t+1\right)}+\frac{V_{d}^{2} k_{d} t}{\left(V_{d} k_{d} t+1\right)}
$$

Where:

$V(t)$ : volume of fluid drained at time $\mathrm{t}$

$V_{g}$ : maximum volume of liquid drained due to gravity drainage process

$V_{d}$ : maximum volume of fluid drained from the gas diffusion

$k_{g}$ : rate constant for the gravity drainage process

$k_{d}$ : rate constant for the gas diffusion process or disproportion.

\subsection{Interfacial Rheology}

The measurements were carried out in a dynamic drop tensiometer (Tracker, IT-Concept, Saint-Clementtes Places, France). The surface dilational properties $\mathrm{E}$ (dilational modulus), and its elastic (Ed) and viscous (Ev) components were determined in the water-air interface, $120 \mathrm{~min}$ after the drop of air was formed in a $1 \mathrm{mg} / \mathrm{mL}$ protein solution in phosphate buffer $\mathrm{pH} 8.0,0.1 \mathrm{M}$ and ionic strength of 0.28 . The amplitude and angular frequency remained constant at $10 \%$ and $200 \mathrm{MHz}$, respectively. The experiments were performed at $20 \pm 1{ }^{\circ} \mathrm{C}$.

\subsection{Statistical Analysis}

Analysis of variance (ANOVA) with $P=0.05$ and mean comparison by least significant difference test (LSD) with $P=0.05$, using Statgraphics plus 7.0.

\section{Results and Discussion}

WPI solubility is greater than the solubility of SPI. The same trend was found in the surface hydrophobicity (Table 1). It is generally observed by the parameters $\mathrm{v}_{\mathrm{o}}$ and VLEmax that the foam ability of WPI is greater than that of SPI, having significant differences $(P \leq 0.05)$ between values (Table 2). This means that WPI had a faster rate of incorporation of the liquid to the foam and was capable to retain more liquid than SPI.

To exert surfactant action, the protein has to be rapidly adsorbed (spread, penetrate, rearranged) at the interface, which requires above all solubility and flexibility, having a low molecular weight that is disociable and having an adequate hydrophilic-lipophilic balance given by the ratio surface hydrophobicity/surface charge [3]. The greater solubility in water and the surface hydrophobicity of WPI account for the better foam ability of WPI.

The values of the gravitational and disproportion drainage constants are presented in Table $2 . \mathrm{kg}_{\mathrm{g}}$ values are an order of magnitude greater than those of $k_{d}$, so that gravity drainage occurs more rapidly than the drainage due to disproportion. In general, in the study of foaming properties it was observed that the foams made with WPI were more stable because it has the lower values of $\mathrm{k}_{\mathrm{g}}$ and $\mathrm{k}_{\mathrm{d}}$ (Table 2).

The mechanisms of destabilization of foams also occur during the formation of foams, therefore, proteins with good foaming ability must be able to counter these mechanisms of destabilization. That is why WPI presented the best foaming capacity and stability. 
Table 1 Solubility (g of soluble protein/100 $\mathrm{g}$ of total protein) and surface hydrophobicity of proteins.

\begin{tabular}{lll}
\hline & Solubility (\%) & Surface hydrophobicity \\
\hline WPI & $80 \pm 2 \mathrm{a}$ & $38.2 \pm 0.1 \mathrm{a}$ \\
SPI & $74 \pm 3 \mathrm{~b}$ & $27.4 \pm 0.3 \mathrm{~b}$ \\
\hline
\end{tabular}

The values that are in the same column with the same letter have no significant differences $(P \leq 0.05)$.

Table 2 VLEmax, $v_{i}, k_{g}, k_{d}, V_{g}, V_{d}$ and for the different samples.

\begin{tabular}{llllll}
\hline $\begin{array}{l}\text { VLEmax } \\
(\mathrm{mL})\end{array}$ & $\begin{array}{l}\mathrm{V}_{\mathrm{i}} \\
(\mathrm{mL})\end{array}$ & $\begin{array}{l}\mathrm{k}_{\mathrm{g}} \times 10^{3} \\
\left(\mathrm{~mL}^{-1} \mathrm{~s}^{-1}\right)\end{array}$ & $\begin{array}{l}\mathrm{k}_{\mathrm{d}} \times 10^{4} \\
\left(\mathrm{~mL}^{-1}\right.\end{array}$ & $\begin{array}{l}\mathrm{V}_{\mathrm{g}} \\
\left.\mathrm{s}^{-1}\right)\end{array}$ & $\begin{array}{l}\mathrm{V}_{\mathrm{d}} \\
(\%)\end{array}$ \\
\hline WPI $7.5 \pm 0.3 \mathrm{a})$
\end{tabular}

The values that are in the same column with the same letter have no significant differences $(P \leq 0.05)$.

WPI foams have the greater foam ability not only due to the greater solubility and surface hydrophobicity, but also for having a more cohesive film at the air-water interface as confirmed in the study of interfacial rheology.

The volume of liquid retained by the WPI is double that retained by the SPI, this may be associated with the higher resistance of the interfacial film formed by the WPI as shown by the results of the interfacial rheology (Table 3). In Fig. 1 it can be observed that the foams made with WPI presented smaller bubbles than those prepared with SPI. When foam is formed all the bubbles have the same size, as the size is governed by the pore diameter of the fretted glass. As they formed, bubbles of the foam formed with SPI collapse faster than the foams made with WPI, as SPI foams have less resistant interfacial films, which is also reflected in the initial rate of liquid transfer to the foam $\left(\mathrm{v}_{\mathrm{i}}\right)$, as WPI has a higher $\mathrm{v}_{\mathrm{i}}$ (Table 2).

In order to investigate how effective the gravity drainage mechanism and Ostwald ripening to the total volume of fluid drained are, the proportions of the fluid volume in the fluid drained by gravity $\left(\mathrm{V}_{\mathrm{g}}\right)$ and drainage volume due to the disproportion $\left(\mathrm{V}_{\mathrm{d}}\right)$ were determined. For both, SPI and WPI, the proportion of fluid drained by gravity was significantly higher (never less than 79\%) than the volume drained by disproportion (Table 2).
Table $3 E, E_{d}, E_{v}$ for the different samples.

\begin{tabular}{llll}
\hline & $\mathrm{E}(\mathrm{mN} / \mathrm{m})$ & $\mathrm{E}_{\mathrm{d}}(\mathrm{mN} / \mathrm{m})$ & $\mathrm{E}_{\mathrm{v}}(\mathrm{mN} / \mathrm{m})$ \\
\hline WPI & $84 \pm 4 \mathrm{a}$ & $81 \pm 4 \mathrm{a}$ & $19 \pm 2 \mathrm{a}$ \\
SPI & $27 \pm 3 \mathrm{~b}$ & $27 \pm 4 \mathrm{~b}$ & $4 \pm 3 \mathrm{~b}$ \\
\hline
\end{tabular}

The values that are in the same column with the same letter are not significant differences $(P \leq 0.05)$.

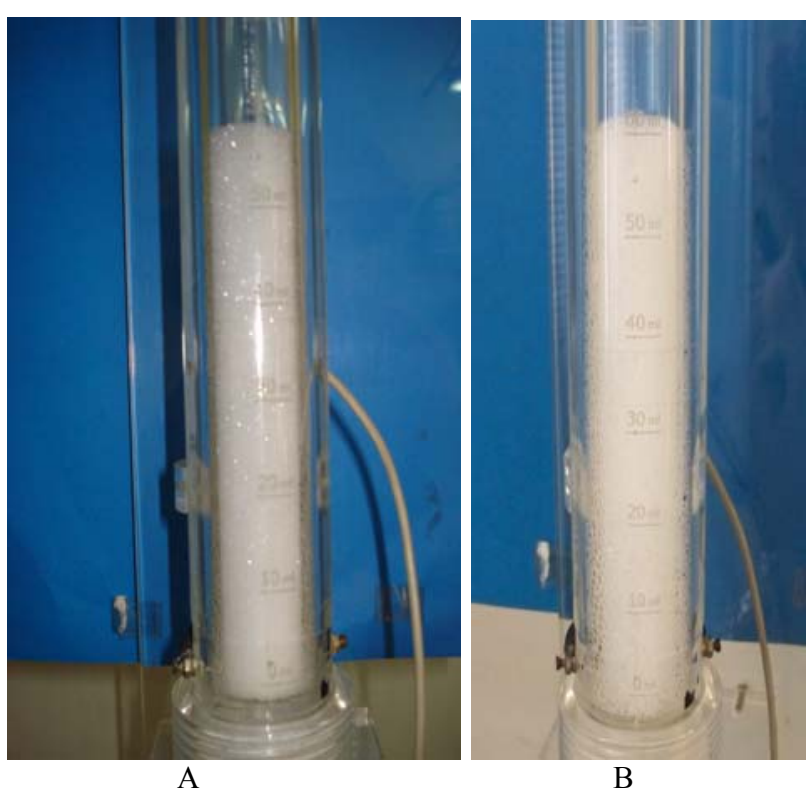

Fig. 1 Pictures of foams prepared with WPI (A) and SPI (B).

It is important to note that the values of $\mathrm{V}_{\mathrm{g}}$ and $\mathrm{V}_{\mathrm{d}}$, unlike $\mathrm{k}_{\mathrm{g}}$ and $\mathrm{k}_{\mathrm{d}}$, depend on each other since they are proportional values. $V_{d}$ values in foams obtained from WPI were significantly higher than those of SPI despite having a greater stability ( $k_{d}$ was significantly lower). This fact can be explained by the greater gravitational drainage stability presented by WPI allowing the phenomenon of disproportion to have time to manifest itself. In the case of SPI the gravitational drainage process was faster and although the process of disproportion was most favored (higher $k_{d}$ ) this contributed to a smaller proportion of the total liquid being drained.

The surface dilational viscosity is crucial for the ability of a surfactant system to form stable foam [26]. The surface viscosity decreases mechanical distortions that might otherwise cause a breakdown of the foam lamellae. But also a stable film requires elastic surfaces to absorb external shocks and, therefore, to prevent rupture of the film [27]. Therefore, both effects are 
important in stabilizing foams. WPI had the highest E, $E_{d}$ and $E_{v}$ indicating that in this case there is a stronger film, which could explain the greater stability of foams prepared with this protein isolate to disproportion and collapse (Table 3 ). The E values for SPI were less than a half of the E values for WPI, as it was previous reported by Rodriguez Niño and collaborators [28].

If a bubble shrinks, its area decreases and its surface load $(\Gamma)$ increases, which does not lead to the provided surfactant desorb. If no desorption occurs, surface tension $(\gamma)$ is lowered, the Laplace pressure is lowered, and the driving force for Ostwald ripening decreases. It will even stop as soon as the surface dilational modulus, $E_{d}$, which is a measure of the change in $\gamma$ with change in area, becomes equal to $\gamma / 2$. However, surfactant normally desorbs and $E_{d}$ decreases, at a rate that depends on several factors, especially surfactant type. Proteins desorb very sluggishly, $\mathrm{E}_{\mathrm{d}}$ remains high, and Ostwald ripening will be greatly retarded [29]. Therefore, as WPI had the higher $\mathrm{E}_{\mathrm{d}}$ presented lesser Ostwald ripening as it can be seen form the value of $k_{d}$.

\section{Conclusions}

These results show that WPI has better foaming ability than SPI, as it has greater values for $\mathrm{v}_{\mathrm{o}}$ and VLEmax. Foams made with WPI also have greater stability to drainage and disproportion (lower $\mathrm{k}_{\mathrm{g}}$ and $\mathrm{k}_{\mathrm{d}}$ ). WPI forms more cohesive films in the interface as deduced from the values of $\mathrm{E}, \mathrm{E}_{\mathrm{d}}$ and $\mathrm{E}_{\mathrm{v}}$ and this is why they were more resistant to disproportion and collapse. In conclusion, WPI had better foaming properties than SPI.

\section{References}

[1] J.M. Rodríguez Patino, M.R. Rodríguez Niño, C. Carrera Sánchez, Implicaciones de las propiedades interfaciales en las características espumantes de proteínas lácteas, in: J. Fontecha, I. Recio, A.M.R. Pilosof (Eds.), Funcionalidad de Componentes Lácteos, CEE Limencop S.L., Alicante, 2009 , p. 71.

[2] J. Maldonado-Valderrama, A. Martín-Molina, A. Martín-Rodríguez, M.A. Cabrerizo-Vílchez, M.J. Gálvez-Ruiz, D. Langevin, Surface properties and foam stability of protein/surfactant mixtures: Theory and experiment, Journal of Physical Chemistry C 111 (2007) 2715-2723.

[3] J.R. Wagner, Propiedades superficiales, in: W. Bartholomai, A.M.R. Pilosof (Eds.), Caracterización Funcional y Estructural de Proteínas, EUDEBA, Buenos Aires, 2000, p. 41.

[4] B.E. Elizalde, D. Giaccaglia, A.M.R. Pilosof, G.B. Bartholomai, Kinetics of liquid drainage from protein-stabilized foams, Journal of Food Science 56 (1991) 24-26.

[5] D. Carp, G. Bartholomai, A. Pilosof, A kinetic model to describe liquid drainage from soy protein foams over an extensive protein concentration range, Lebensmittel Wissenschaft und Technologie 30 (1997) 253-258.

[6] J.P. Davis, E.A. Foegeding, Comparisons of the foaming and interfacial properties of whey protein isolate and egg white proteins, Colloids and Surfaces B: Biointerfaces 54 (2007) 200-210.

[7] D.A. Sorgentini, J.R. Wagner, Comparative study of foaming properties of whey and isolate soybean proteins, Food Research International 35 (2002) 721-729.

[8] D.A. Rickert, L.A. Johnson, P.A. Murphy, Functional properties of improved Glycinin and $\beta$-conglycinin fractions, Journal of food science 69 (2004) 303-311.

[9] L.A. Panizzolo, L.E. Mussio, M.C. Añón, A kinetic description for the destabilization process of protein foams, International Journal of Food Properties 15 (2012) 60-68.

[10] H.E. Swaiswood, Characteristics of milk, in: O.R. Fennema (Ed.), Food Chemistry, Marcel Dekker, New York, 1996, p. 841.

[11] P. Walstra, R. Jenness, Química y Física Lactológica, Acribia S.A., Zaragoza, España, 1984, p. 84.

[12] L.M. Huffman, The importance of whey protein fractions for WPC and WPI functionality, in: Whey, Proceedings of the Second International Whey Conference, 1998, pp. 197-205.

[13] W.R. Egbert, Isolated soy protein: Technology, properties, and applications, in: K.S. Liu (Ed.), Soybeans as Functional Foods and Ingredients, AOCS Press, Champaign, United States, 2004, p. 134.

[14] S. Rouimi, C. Schorsch, C. Valentini, S. Vaslin, Foam stability and interfacial properties of milk protein-surfactant systems, Food Hydrocolloids 19 (2005) 467-478.

[15] S. El-Shiniby, A.F. Farrag, G. El-Garawany, F.M. Assem, Rheological and functional properties of whey protein protein concentrate and $\beta$-lactoglobulin and $\alpha$-lactoalbumin rich fractions, Internacional Journal of Dairy Science 2 (2007) 196-206.

[16] C. Schmitt, C. Bovay, M. Rouvet, S. Shojaei-Rami, E. Kolodziejczyk, Whey protein soluble aggregates from heating with $\mathrm{NaCl}$ : Physicochemical, interfacial and 
foaming properties, Langmuir 23 (2007) 4155-4166.

[17] I. Nicorescu, C. Vial, E. Talansier, V. Lechevalier, C. Loisel, D. Della Valle, et al., Comparative effect of thermal treatment on the physicochemical properties of whey and egg white protein foams, Food Hydrocolloids 25 (2011) 797-808.

[18] N.A. Deak, P.A. Murphy, L.A. Johnson, Characterization of fractionated soy proteins produced by a new simplified procedure, Journal of the American Oil Chemists' Society 84 (2007) 137-149.

[19] J.R. Wagner, D.A. Sorgentini, M.C. Añón, Thermal and electrophoretic behavior, hydrophobicity, and some functional properties of acid-treated soy isolates, Journal of Agricultural and Food Chemistry 44 (1996) 1881-1889.

[20] M. Yu, S. Damoradan, Kinetics of destabilization of soy protin foams, Journal of Agricultural and Food Chemistry 39 (1991) 1563-1567.

[21] S. Petruccelli, M.C. Añón, The realtionship between the method of preparation and the structural and functional properties of soy protein isolates: Part I. Structural and hydration properties, Journal of Agriculture and Food Chemistry 42 (1994) 2161-2169.

[22] O.H. Lowry, N.J. Rosebrough, A.L. Farr, R.J. Randall, Protein measurement with the folin-phenol reagent, Journal of Biological Chemistry 193 (1951) 265-275.
[23] S. Hayakawa, S. Nakai, Relationships of hydrophobicity and net charge to the solubility of milk and soy proteins, Journal of Food Science 50 (1985) 486-491.

[24] A. Kato, S. Nakai, Hydrophobicity determined by a fluorescence probe method and its correlations with surface properties of proteins, Biochimica et Biophysica Acta 624 (1980) 13-20.

[25] W. Loisel, J. Guéguen, Y. Popineau, A new apparatus for analyzing foaming properties of proteins, in: K.D. Schwenke, R. Mothes (Eds.), Food Proteins, Structure and Functionality, VCH, Weinheim, 1993, p. 320.

[26] P. Koelsch, H. Motschmann, Relating foam lamella stability and surface dilational rheology, Langmuir 21 (2005) 6265-6269.

[27] C. Stubenrauch, R. Miller, Stability of foam films and surface rheology: An oscillating bubble study at low frequencies, Journal of Physical Chemistry B 108 (2004) 6412-6421.

[28] M.R. Rodríguez Niño, C. Carrera Sánchez, V. Pizones Ruíz-Henestrosa, J.M. Rodríguez Patino, Milk and soy protein films at the air-water interface, Food Hydrocolloids 19 (2005) 417-428.

[29] P. Walstra, Dispersed systems: basic considerations, in: O.R. Fennema (Ed.), Food chemistry, Marcel Dekker, New York, 1996, p. 95. 